\title{
Address: Critical irony, neo-authenticity and humour in the art we call public
}

Article

Accepted Version

Garnett, R. (2017) Address: Critical irony, neo-authenticity and humour in the art we call public. Art and the Public Sphere, 1 (6). pp. 69-79. ISSN 2042-793X doi:

https://doi.org/10.1386/aps.6.1-2.69_1 Available at https://centaur.reading.ac.uk/70157/

It is advisable to refer to the publisher's version if you intend to cite from the work. See Guidance on citing.

To link to this article DOI: http://dx.doi.org/10.1386/aps.6.1-2.69_1

Publisher: Intellect Journals

All outputs in CentAUR are protected by Intellectual Property Rights law, including copyright law. Copyright and IPR is retained by the creators or other copyright holders. Terms and conditions for use of this material are defined in the End User Agreement.

\section{www.reading.ac.uk/centaur}

\section{CentAUR}

Central Archive at the University of Reading

Reading's research outputs online 


\section{Address: Critical Irony, Neo-Authenticity and Humour in the Art we Call Public}

One of the reasons I was invited to write this text was an anecdote attributed to me by Dave Beech, one of the editors of this journal.

Sometime back in the late 90s, Dave has recounted, I once said after a few beers in a public house that 'the only art that doesn't' have a public is Public Art'. Until recently reminded of this - the quote appears on this journal's website - I'd long forgotten that I'd said it, and my intended meaning at the time is beyond my recall. However, it strikes me now as being a concise and pithy-sounding, somewhat sarcastic sound bite, typical of a pub conversation. At the same time, however, it's not absolutely clear what it means - thinking about it, it could be both right and wrong, and in different and contradictory ways.

One could in a text on public art have devoted it to the impossibility of thinking just such a public art. One could have deconstructed the distinction between the public and privatised sphere in a number of different ways. How, for example, in our algorithmically digitised, semiocapitalist psychosphere, that cuts across the public and private, can we think a distinct category of a public art. Both the privatisation of public space, within which much usually privately-funded public art is installed, along with Big Data, surveillance and the internetdriven evisceration of the interiority private domain make it impossible to conceive of any such distinctions. With the hyper-spectacularization of the art institution, what public work of art can have the same impact as the edifice of the Guggenheim Bilbao or Tate Modern as in themselves total works of public art. Some of the things they contain, frame and render visible, both within and beyond their dematerialised walls, is far more publicly visible than almost any examples of public art, precisely because of that 
institutional frame. Regarding he web, what work of public art has had more impact in recent years than Ryan Trecartin's open-access Center Jenny on Vimeo. However, the art we call public still exists, and there has never been more public sculpture; more of it is installed everyday, and these works still address 'us'. So here I wish to think about the specific modes of address of these works, and the quite radically distinct ethics, aesthetics and politics that constitute the very ways in which that 'us' is implied and inscribed.

\section{Irony, or 'art about art about art'}

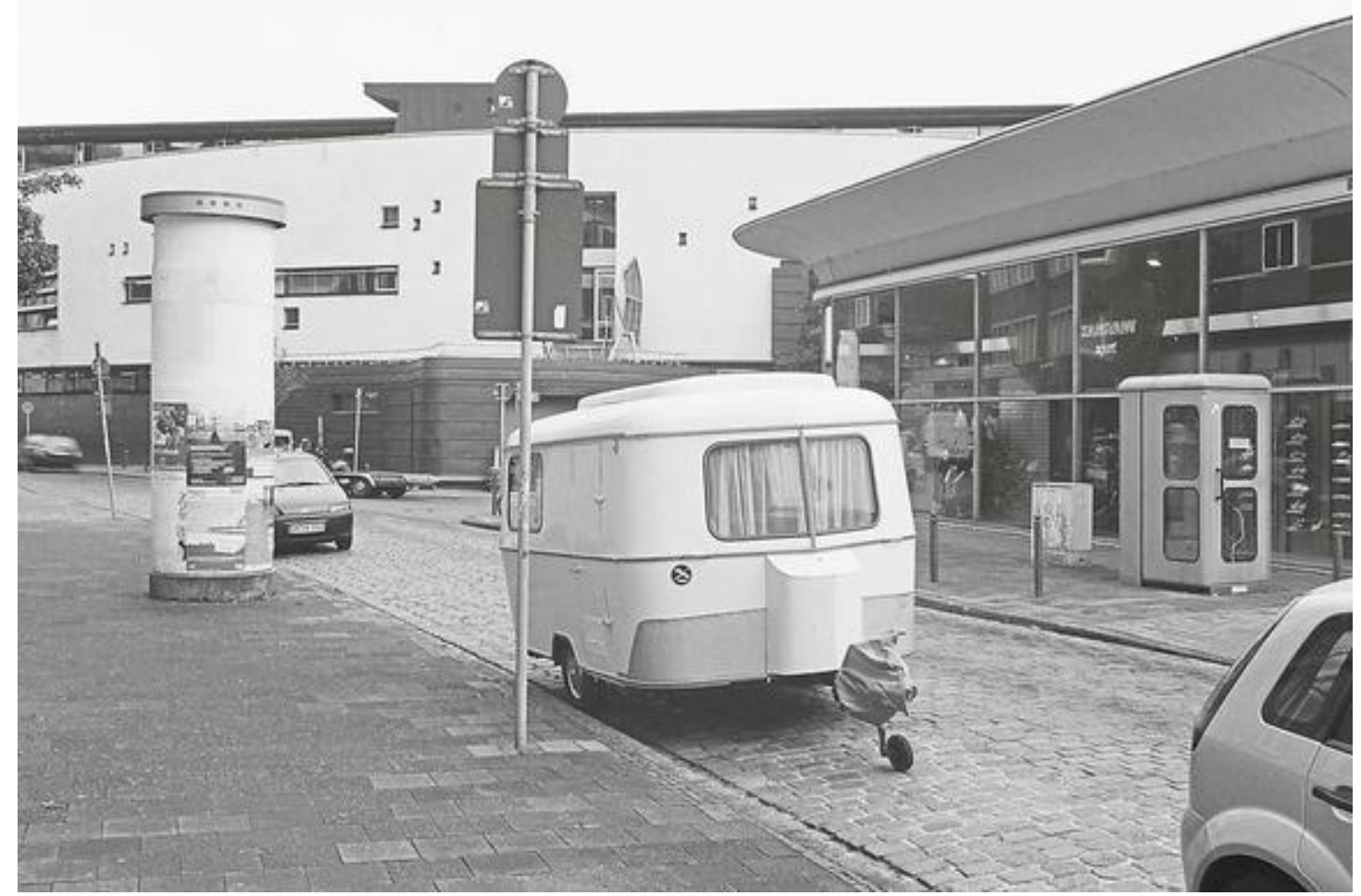

Fig. 1: Michael Asher, Project: Installation (Caravan), 1977

One piece of Public Art that immediately sprung to mind when I recounted this was a work that I've recently been thinking about that does indeed illustrate this quote in one particular respect. It is not a work that I've ever been 
that enthusiastic about but it is one that has long since acquired iconic status, and is seen to be paradigmatic of certain kinds of interventions by artists into the 'public' domain. As such it is on almost every academic slide list devoted to discussions of both Institutional Critique and art in the public sphere. The work I'm thinking of is Michael Asher's Project: Installation (Caravan), made for the first Munster skulptur Projekt in 1977, and reinstalled every 10 years for each subsequent iteration of what is still one of the most high-profile displays of public and site-specific art works. It consists simply of a small holiday caravan installed on its own on an ordinary street in the city. An inverted Duchampian unassisted readymade in reverse, the piece displaces Asher's typical critical concerns with the institutional frame of the museum and gallery to that of public art as institution. The work is a piece of critical meta-art about about the impossibility of public art, and is a kind of founding statement of its kind.

\section{The Problem With Critical Irony}

Asher's fellow High Priest of 'Inst Crit', Andrea Fraser, once professed to 'love' the work, and cited it as something of an epiphany in the development of her own practice. Her words, as far as I remember them, were that the work demonstrated that 'a work of art has no substantive quality that distinguishes it from any other object in the world apart from the fact that it is the object of a specialised, professionalised gaze that singles it out in advance as a work of art. ${ }^{i}$ The caravan makes its point with Asher's typical concise economy, but its point, however, is only amenable precisely to the bearer of that specialised, professional gaze; it is thus necessarily exclusive. The work, in order to make its point, intended to exclude 
the non-initiated; it was designed to be invisible to the 'public' at large. Indeed in its last installation at Munster in 2007 it was intentionally locked up in a garage for 5 weeks.

Freud in his book on jokes referred to irony as a means of doing or saying one thing and clearly meaning another. (Freud 1960: 181) Like a sarcastic in-joke, however, it can only mean, can only represent if the audience is prepared in advance to 'get' the point of the rhetorical utterance. Irony is knowing, and is dependent upon a knowing in advance. In Asher's case his work is knowingly positioned in relation to a contiguous critical constituency in a way that became the blueprint for later critical 'Kontext Kunst', as it would be called in Germany. It is thus 'readymade' in another sense, in that it is a putting into practice of a prior critical position specifically directed towards a readymade 'public'. As much as it site-specific, the work is therefore discourse-specific, and in many ways the former is dependent upon the latter.

Deleuze makes a point regarding irony as being a 'superior' mode that always arrives in advance for the encounter with the Event of art and thus misses it; humour, on the other hand, is the art of being open to the event-encounter where the 'intelligence always comes later'(Deleuze 2004: 30). Philosophical irony has its roots in the Socratic mastery of the Platonic dialectic, inaugurating a continuum that extends through Romanticism - the early Jena version - up to our present-day, post-Postmodern critical negative theologies. Regarding the latter, Foucault famously stated of Deleuze's distinction between irony and humour that 'irony rises and subverts; humour descends and perverts'(Foucault 1977: 165). The ironist rises to a transcendent Idea in our case here these would be Unity and autonomous Art - and descends in order to critically demonstrate their impossibility, their 
unthinkability. Deleuze describes ironists as 'Men of conversation', and their 'tone is always of the signifier. He constantly goes up and down'. Humour is 'completely the opposite', Deleuze continues, it is, 'completely atonal, absolutely imperceptible, it makes something shoot off. It never goes up or down, it is on the surface: surface effects. Humour is an art of pure events'. Humour takes one to the Outside of signification; it aims to stop the good conversation' in its tracks, to confound it in favour of producing New questions: 'the art of constructing a problem. None of this happens in an interview, a conversation, a discussion' (Deleuze and Parnet 1987: 68).

\section{PUBLIC ART DOES IN FACT ATTEMPT TO DEAL WITH NOT ONLY ALIENATION BUT AS WELL TO HELP ITS CITIZENS FIND THEIR PLACE IN THE SUN}

Today's art world is defined precisely by its status as a non-stop curator-led talking shop. After our recent conversational turn, whole art works, whole public art projects, whole Biennales can be conceived as 'immaterial' conversations. However, talking about art, politics and political art only takes us so far. Thomas Hirschorn has frequently borrowed the following phrase from Jean Luc Godard when he refers to 'wanting not to make political art but to make art politically'. What would such an art 'look like'. Maybe it would not look like anything, maybe it would not be the object of recognition, or knowledge, or mastery of anyone's professionalized gaze at all. Maybe it would be something that rather than being deadlocked in the Capitalist Realism of the present would actively produce outsides of the present. Such an art would incarnate Events, and Events, however small or big, render the present pre-posterous by producing blocs of duration that contract and dilate the present into the past and the future of the past or the future past of the present. 


\section{OVER AGAIN BEFORE}

Events actively produce a palpable sense of a non-teleological futurity disarticulated from the deadlocked present (that is tellingly almost always prefixed by a post-...). This is precisely what no punctual conversation, populated by what Nietzsche would have called 'Men of the present' can achieve.

\section{THEN NOW \& THEN}

The creation of an untimely event is exactly what art does politically that (what passes for) politics cannot do. No Event has ever been curated into ex-istence.

In recent years there has been a reaction against irony in favor of what I'll refer to here as NeoAuthenticism'. This has taken the form of a rejection of exclusive, academic discoursespecific, indirect speech in favor of the more direct address of a revival of 'realisms' (much so-called 'post-internet' art would fall into this category in spite of its 'medium' and numerous kinds of direct social functionalisms. One notable example of this was the first postOccupy Berlin Biennale, whose press conference notoriously opened with the following curatorial announcement: 'You can sum up my position in one sentence: art does not work and art does not act'. Since then, no Biennale has been complete without curated forms of collective, 'sociallyengaged' curated projects, quite often staged as supplements to the main event. On the one hand we have the persistence of late-Postmodern indirect address of the politics of representation', what Jerry Saltz has called 'art about art about art' of critical spatial practices, and then a recent injunction for art to get 'real', which 
represents a return to the representation of politics, and/or an art that directly addresses the social sphere as literal political intervention. The latter, if Art and Education website is anything to go by, is a highly profitable growth area in art education with new MFAs in socially engaged art being announced on an almost weekly basis. Much of this, however, harks back to very much un-curated activities of previous decades, particularly the 70s, and it coincides with a compensatory nostalgia for those days when such practices could claim to be embedded in the social and political movements that might have prevailed at the time. Disarticulated from these spheres of public-ness, though, do such calls to action, in the grander scheme of things, and in spite of their laudable intentions, amount to anything much more than gestures; do they, as is often the case, amount more to grand curatorial statements directed largely at the art world itself. Take, for example, 'documenta 14' that recently opened in Athens, a project that exceeds my Berlin example as being the most emphatic and unequivocal injunction to the art world at large to get 'real' and address the Now beyond the confines of the art world. Again it is a call made by the most arch insiders of the art world - curators that will inevitably fail to resonate very far beyond its borders. However, as I will argue in a moment, for me, this might not be the most productive way to frame the question of art's political agency in and on the world.

Nevertheless, the dominance of this question in the art world over last decade since the 'activist turn' (as I write even current issue of Frieze, the Bible for 'art fair art', has protest art as its main theme) has enabled a largely curatorial constituency to secure their place atop the moral high ground of an art world even more deeply divided around the unproductive and moribund binaries of a 'dependent' or

'autonomous' art versus a 'political' art; and/or 
a disengaged 'formalism' versus a 'sociallyengaged' would-be praxis. The latter is usually prefixed by one of those privileged terms 'collective', 'group', or 'participatory', which is then inevitably pitched against the 'outmoded' model of the individual author artist - as if this and the aforementioned oppositions hadn't been deconstructed to death decades ago.ii

One of the ways in which an art of direct social engagement (and therefore an 'authentic' political art) consolidates its moral superiority is via the familiar mechanism of a double alibi, which, to paraphrase Hal Foster, goes something like this: on the one hand such an art can excuse itself from having to be new and confoundingly different or self-different as art because it's 'political' art; on the other, it can excuse itself from having to be actually effective as politics because it's 'political' art. It can therefore get away with being such calls to 'real' action can get away with being curatorially 'radical' while being aesthetically conservative and ineffective as political praxis - all the while, we might add, being just as dependent upon the category of autonomous art as any art-for-art's sake formalism.

It is, however, hard to argue against the moralisms of social engagement, however problematic they might be, because one immediately risks being cast as a-political, amoral. But maybe we should bypass the false moral question, forget normative morality and move to the much less self-certifyingly safe ground of the (undecidable) pragmatics of ethics. Maybe it would be much more productive to address the question raised by Psychoanalysis since Lacan and ask whether they're right when they argue that the ethics of psychoanalytical practice as well as art practice might have nothing at all to do with the moral 'service of goods'. Maybe art, to cite Blanchot, or Lazzarato is an a-social form of social engagement, an un-working that might 
have nothing at all to do with means-ends instrumental rationality. Lawrence Weiner has frequently reiterated that he doesn't just want his work 'to be a distraction for people on their way to work', he wants his art to 'fuck up people's entire lives' (Weiner 2013). This is a big claim, but I want to take it seriously. However, he's not addressing just 'us' art world insiders - we're hopefully fucked up already. Furthermore he's maybe not addressing 'us' as we are at all ... his art - in its modest but effective way - intends to produce Events that render us 'pre-posterous', that actively disarticulate our words from the world of things. This might be what what art does politically that politics or political art can't seem to do. Events fuck up your everyday life coordinates ... both irony and authenticity, however, repress the event; neither have space or time for the untimely encounter. They are ultimately reverse sides of the very same coin.

From the outset, Weiner's art departed from a 'contextual' 'conceptualism' founded upon a reading of the Duchampian Readymade as an act of spatial displacement - of which Asher's reversed readymade taken back into the street is still an example - in favor of the Duchamp of the 'infrathin' time of the Event. Lawrence Weiner and Robert Smithson were just such artists who were concerned with rendering 'public' not an abstract, spatialised, clock time of past, present and future in linear sequence, but with the perverse offspring of Chronos, or Father Time, Aieon, who is the $4^{\text {th }}$ dimension of time.

\section{TIME IMPEDED}

Bergson argued that logical time is an abstraction of the intellect, whereas the twisted, perverted time of duration is only amenable to sensible intuition. Duration, Deleuze argued, incarnates pure difference, which is that 
which is not only different to all others but is different from itself.

\section{INSIDE \& OUTSIDE OF ITSELF}

This conception of art's self-differential specificity (or what an Adornian might call nonidenticality) takes us beyond questions of autonomy and its critique

Lawrence Weiner has probably been the most prolific 'public' artist of recent decades; I can think of no other artist who has installed more works in the spaces we call public than him since the late $60 \mathrm{~s}$. The mode of address of these works is neither ironic nor first-personally sincere. Rather, they are humorous, and humour is the art of the $4^{\text {th }}=$ personal singular, or free-indirect discourse, a kind of reported speech unattributable to any identifiable speaker.

\section{AM OUT OF CONTEXT WITH THE WORK}

Weiner has also insisted upon the work's

'universal availability', that the works are nonexclusive without at all, as we'll see in a moment, being populist (Weiner 2004: 177).

His text-based works invariably take the form of a sequence of words, most often including the past participle of a verb, re-petitioned in such a way that they are always left incomplete, or as Duchamp would have put it, 'definitively unfinished'. His 'Statements' always refer to what he describes as an 'established empirical fact' but, at the same time, they are always somewhat elliptical, and this in a double sense. Firstly, while referring to a completed action in a minimally reduced, zero-degree linguistic form they nonetheless remain confoundingly and paradoxically enigmatic. In the same way as Deleuze said of Foucault's theory of statements, 
or enonces, first published in 1968 - and perfectly contemporaneous with Weiner's book, Statements, of the same year - they are 'secretive but with absolutely nothing being hidden'. Weiner presents words in their raw state as 'some language', in much the same matter-offact way as his friend and fellow artist, carl Andre, presented raw materials. The infinitive character of his statements is often augmented by the inclusion of the graphic device of an ellipsis or an open ellipse. The latter often encircles an indefinite article, an 'a', that as Weiner has stated, refers to 'a specific object without a specific form'. He has spoken of this as his 'medium', and how the infinitive and the indefinite actively 'objectifies desire', how it activates our default hard-wired-ness for completion and closure, while at the same time producing a sense of anticipation and futurity. Devoid of any melancholic irony, they are actively...pre-posterous in the same sense as I have used the term thus far. And being poised between something that has happened and something about to happen, they are akin to what Deleuze and many other thinkers would call an Event. An Event is always in the middle; it begins and ends in the middle, in the aternal interstice between the happened and the about to happen. It is never 'happening' in the sense that it is never a punctual and self-present object of recognition. Rather, Weiner's Event-statements suspend language, suspend sense in the aternal interstice of the tense-less 'meanwhile'.

Complete nonsense would, however, obviously fail to achieve this, and Weiner's statements work due to their perfectly pitched, intensive suspension between sense and its absence. As Deleuze again states with regard to the 'logic of sense', here the 'signifier is floating and the signified is floated' (Deleuze 1990: 89). 


\section{THE GRACE OF A GESTURE}

To Giorgio Agamben, the gesture is a fundamentally ethical phenomenon and, moreover, it also constitutes the minimum form of the political (Agamben 2012). The same would, I'm sure go for Lawrence Weiner too. For Agamben, poetic language is defined by its status as a pure gesture. Pure gestures are a paradoxical kind of communication without communication consisting of 'signifiers without signifieds' that are, in this respect, very much akin to what Weiner refers to as his 'non-impositional' units of linguistic interpolation that are poetic without being anything like conventional poetry. A pure gesture is, like a Foucauldian statement, a minimum form of discursivity that nonetheless opens up an interface with another, with alterity. It does this, though, in a noninstrumental 'un-working' linguistic mode, constituting a disjunctive-syhthetic a-social kind of sociality, or a relationality without relation, quite unlike the 'relational' or 'participtatory' aesthetics' of recent yore.

Neither an exchangeable unit of communication or information, nor utter nonsense, Weiner's works are perfectly

\section{PITCHED}

Between sense and its absence

\section{BETWEEN DISSOLUTION \& RESOLUTION (AT A GIVEN TIME)}

This is how the works 'work'. Nonsense would be an immediately readable gesture of the refusal to engage with the interlocutor, whereas the pure gesture intensively suspends signification and amounts to an ethical means of 'fucking up' the interface between our words and the everyday world of things in the public sphere. 


\section{IF IN FACT THERE IS A CONTEXT}

Counter-intuitively for such a prolific public artist, Lawrence Weiner has stated that he has never made a site-specific work in his entire career. Rejecting contextualism long before Kontext Kunst he has from the outset insisted that 'content is context'. What might this content be? It would not be the literal content of the statements themselves but the preposterous excess they produce - the eventuality of the statements. A useful way of thinking this dimension of his work is via another of Deleuze and Guattari's concepts, that of the rhythmic Refrain that is developed in their magnum opus, A Thousand Plateaus - a concept that Weiner's work uncannily prehends (Deleuze and Guattari 1988: 330-369). The refrain is a theory of rhythm as a territorial assemblage and offers a way of thinking about how art acts intensively in and on the world, how rhythmic assemblages, like the birdsong example they deploy, actively de- and reterritorialises any given space upon which art acts upon.

SCULPTURE BY VIRTUE OF ITS STATE

PRESENTS A MATERIAL REALITY THAT BY ITS PRESENCE CHANGES THE INHERENT MEANING OF WHATSOEVER

PLACE

IT FINDS ITSELF

BRINGING ABOUT A CHANGE IN THE RELATIONSHIPS OF HUMAN BEINGS \& OBJECTS \& PRODUCING A CHANGE IN THE AMBIENCE

CAVEAT EMPTOR: IT CAN SOMETIMES BLOCK THE WAY

Like musical rhythm, the infinitive dimension of Weiner's works is always in the middle; they exist in the in-between the happened and about to happen. Debussy once said something that many subsequent musicians have reiterated in various ways, that music exists in the space between the 
notes or beats. Music, or rhythm, is the outside of musical form. At more or less the same time, Bergson also compared pre-posterous duration to a continuous and infinitive melodic flow. When rhythm in music really works, really moves the listener we lose all sense of linear, spatialised time; we ex-ist, lose ourselves in the intensive interstice between the still palpable just passed and the equally palpable anticipation of the next beat. Here, to reiterate presence is folded and twisted into the past and the future of the past - the future-past of the present. In this way, rhythm produces a palpable sense of a nonteleological futurity in and out of here and now.

\section{THE OBJECTIFICATION OF A MISE EN SCENE FOR THE PRESENTATION OF CONTENT IS THE RESULT OF THE INHERENT MATERIALITY OF BOTH LANGUAGE AND SOUND}

Elsewhere in the Refrain, Deleuze and Guattari discuss the territorializing function of art. They compare the artist to a virtual 'stage maker', of which are the mark, the poster and the placard as functional elements (354). Here, perhaps like Weiner, they reclaim an autonomy for artistic agency in and on space. This is not autonomy in any prior, transcendent sense but as something that art actively produces. It is the mark or the placard, they argue, that 'makes the territory'. 'The territory is a function of decoding', they continue, and 'this demarcation constitutes a home, but the home does not preexist. The natal is always outside'(356).

This already begins to offer us a way of rethinking art in the spaces we call public that recomplicates and takes us beyond contextualism and notions of art as intervention into preexisting spaces. And, further on, they compare the agency of the artist - one that is again 
uncannily like Weiner - to the public verbal and physical gestures of merchants and traders in their performative creation of what I have called elsewhere 'pitches' or ex-centric ambient zones in and on but irreducible to 'context', 'market' or otherwise. To cite the Refrain again, the centres of these pitches of intensity 'are simultaneously inside the territory and outside the several territories that converge upon it' (359).

\section{A SERIES OF STAKES SET IN THE GROUND AT REGULAR INTERVALS TO FORM A RECTANGLE TWINE STRUNG FROM STAKE TO STAKE TO DEMARK A GRID A RECTANGLE REMOVED FROM THIS RECTANGLE}

If the rhythmic event opens onto the outside of linear time, the $4^{\text {th }}$ dimension of time, then what Weiner refers to as ambience might be thought of as the $4^{\text {th }}$ dimension, or outside, of the three dimensions of Euclidean space. As excess of linear time and spatial extensity, events are of durational intensity but are at the same time, as Weiner insists, 'a material reality'. Ambience offers us a different way of thinking Deleuze's notions of the 'actuality of virtual' and the virtuality of actual, and how art's function is to actualize virtual events within which are incarnated future potentialities.

\section{WITHIN THE CONTEXT OF NON-PARALLEL REALITIES (MULTIPLE REALITIES OCCUPYING THE SAME SPACE AT THE SAME TIME)}

This is precisely the argument of Franco Berardi 'Bifo' in a recent essay (Berardi 2011). He also deploys Deleuze and Guattari's concept of the refrain, retournel, or rhythm, and demonstrates 
its vital contemporary politicality through showing how rhythm has the capacity to 'produce an autonomy which constitutes the independence of social time from the temporality of capitalism'. 'Digital financial capitalism has created a closed reality, he argues, which cannot be overcome using the techniques of politics of conscious organized voluntary action and government'.

Schizoanalysis, of which the refrain is an instrument, acts in two ways, Berardi argues: 'it diagnoses the infospheric pollution of the psychosphere, but it also provides treatment to the disturbed organism. The retournel is the sensitive niche where we can create a cosmos that elaborates chaos'. The refrain can be 'insurrectionary', he continues, 'and helps to withdraw the psychic energies of society from the standardised rhythm of compulsory competitionconsumption and create an autonomous collective sphere'. To him, poetry, or art, or music is the 'language of movement' as it deploys a new retournel. Counter to the new modes of standardisation and submission that subjectivity undergoes, produced by network technologies and neo-liberal globalisation, 'refrains are pathways of autonomous subjectivisation', or the production of new group subjectivities in and through the creation of heterogenous rhythm. Rhythmic retournels as instruments of schizoanalysis achieve 'a singularisation and sensibilisation of breathing, unchained from the congealed pace of the immaterial assembly line of capitalist production'. This, to conclude, is precisely what art does politically that politics cannot. 


\section{References}

Agamben, G. (2012) Gesture, or The Structure of Art - youtube

Berardi, F. 'The Emancipation of the Sign' e-flux online

Deleuze, G. (1990), The Logic of Sense, ed. C. Boundas, trans. M. Lester with C. Stivale, New York: Columbia.

Deleuze, G. (2004), Proust and Signs, trans. R. Howard, Minneapolis: University of Minnesota P. Press.

Deleuze, G. and Guattari, F. (1988), A Thousand Plateaus, trans. B. Massumi, New York and London: Athlone

Deleuze, G. and Parnet, C. (1987), Dialogues, trans. H. Tomlinson and B. Habberjam, New York: Columbia

Foucault, M. (1977), 'Theatrum Philosophicum', in Language, Counter-Memory, Practice, ed. D. Bouchard and L. Simon, Ithaca: Cornell University Press

Freud, S. (1960) Jokes and Their Relation to the Unconscious, trans. J. Strachey, Harmondsworth: Penguin Freud Library

Guattari, F. (2009) Soft Subversions, Texts and Interviews, 1977-1985, ed. S. Lotringer, Trans. C. Winer and E. Wittman, Cambridge, Mas.: MIT Saltz, J.

Weiner, L. (2004), HAVING BEEN SAID, The Collected Writngs and Interviews of Lawrence Weiner, Ostfilden: Hatje Cantz. Weiner, L. (2008), AS FAR AS THE EYE CAN SEE Weiner, L. (2011), IF IN FACT THERE IS A CONTEXT, Ostfilden: Hatje Cantz. Weiner, L.(2013), 'Interview at Stedlijk, Amsterdam' Weiner, L. and S. Hayes (2010) Discussion 
${ }^{i}$ This quote from Andrea Fraser is not verbatim because the online recording of a number of talks within which she made these statements has been taken offline. Fraser has been particularly active in policing her online presence over recent years. I hope that the reader will trust that I my citation of these statements is made in good faith.

ii Guattari, in 1981: "I no longer have much faith in the specificity of the group, and I would even say that I believe less and less in the group as an entity'. Most of the time it's no more than a fiction'. Continuing, he argues that ' 